\title{
ANALISIS BEBAN KERJA DAN GAP KOMPETENSI UNTUK PERENCANAAN SUMBER DAYA MANUSIA TENAGA KEPENDIDIKAN
}

\author{
WORKLOAD ANALYSIS AND COMPETENCE GAP FOR \\ HUMAN RESOURCES PLANNING IN EDUCATION
}

\author{
Susanti" ${ }^{* 1}$, M Syamsul Maarif", dan Mukhamad Najib**) \\ *) Sekolah Bisnis, IPB University \\ Jl. Raya Pajajaran, Bogor 16151 \\ ${ }^{* *}$ Departemen Manajemen, Fakultas Ekonomi dan Manajemen, IPB University \\ Jl. Agatis Kampus IPB Darmaga, Bogor 16680
}

\begin{abstract}
The study's purpose was to analyze the workload and tendency competency gaps in Faculty A of XYZ University, and to recommend HR planning of academic staff at Faculty A in XZY University. The workload analysis and competency gaps analysis used to determine the ideal number of academic staff that needed as well the competencies. The results were expected to be used in planning academic staff in Faculty A. The results showed that the released ideal number of academic staff by the Directorate of Human Resources of the University of XYZ in 2012 to 2030 was no longer relevant for use. Currently, there were 97 academic staff exist in Faculty A. It was higher than an ideal of 81 persons from the workload analysis findings. There were competency gaps in both core and managerial. The findings suggested policies to reduce academic staff, especially noncivil servants, by continuing to prioritize applicable regulations.
\end{abstract}

Keywords: competency, competency gap Analysis, HR planning, workload, workload analysis

\begin{abstract}
Abstrak: Tujuan penelitian ini adalah menganalisis beban kerja dan gap kompetensi tendik pada Fakultas A Universitas XYZ, dan merekomendasikan perencanaan SDM tendik di Fakultas A Universitas XZY. Analisis yang digunakan dalam penelitian ini adalah analisis beban kerja untuk menentukan kesesuaian jumlah ideal tendik yang dibutuhkan serta analisis gap kompetensi untuk mengetahui kesesuaian kompetensi. Hasil penelitian ini diharapkan dapat dijadikan landasan dalam perencanaan tendik di Fakultas A. Hasil analisis menunjukan bahwa jumlah tendik ideal yang dirilis Direktorat SDM Universitas XYZ tahun 2012-2030 sudah tidak relevan lagi untuk digunakan namun keberadaan tendik eksisting saat ini sebanyak 97 orang yang dimiliki oleh Fakultas A. Hal tersebut sudah terlalu banyak, bila dibandingkan dengan hasil analisis beban kerja yang sebanyak 81 orang. Hasil penelitian juga menunjukan masih ada gap baik pada kompetensi inti maupun kompetensi manajerial. Berdasarkan hasil direkomendasikan kebijakan pengurangan tendik terutama non PNS tentu dengan tetap mengedepankan peraturan yang berlaku.
\end{abstract}

Kata kunci: kompetensi, analisis gap kompetensi, perencanaan SDM, beban kerja, analisis beban kerja

\footnotetext{
${ }^{1}$ Alamat Korespondensi:

Email: susanti.usman@gmail.com
} 


\section{PENDAHULUAN}

Pada organisasi, perencanaan sumberdaya manusia (SDM) memiliki posisi yang penting. Ketepatan maupun kesalahan dalam perencanaan SDM akan memberikan dampak, baik itu positif maupun negatif terhadap organisasi. Begitu pentingnya perencanaan SDM hingga Hasibuan (2013) menyatakan bahwa perencanaan SDM merupakan fungsi pertama dan utama dalam manajemen SDM.

Pada lembaga penyelengaraan pendidikan tinggi, selain peran dari masing-masing lembaga dalam merencanakan SDM yang dimilikinya maka kebijakan pemerintah pun memiliki peran penting terhadap perencanaan SDM pada lembaga pendidikan tinggi tersebut (Benitez et al. 2016), seperti tercantum dalam UU No 12 Tahun 2012 tentang Pendidikan Tinggi tepatnya pasal 69 yang mengatur tentang Ketenagaan dalam sebuah perguruan tinggi yang terdiri dari dosen dan tenaga kependidikan (tendik) sebagai SDM yang amat penting terhadap berjalannya proses bisnis pendidikan tinggi yang kompetitif dan terbuka seperti yang disampaikan Teir dan Zhang (2016). Sebelumnya, Rabee (2014) mengatakan juga bahwa dalam perkembangan lembaga pendidikan tinggi, inovasi terhadap perencanaan SDM merupakan hal yang terpenting. Sehingga merupakan hal yang penting untuk melakukan perencanaan SDM guna mendapatkan tendik yang efektif, sebagaimana Allui dan Sahni (2016) sampaikan bahwa sebagai industri padat karya seperti pada lembaga pendidikan tinggi maka penggunaan SDM yang efektif menjadi sangat penting.

Berdasarkan Fahmi (2016) perencanaan SDM dapat dilakukan dari dua sisi baik itu secara kuantitas maupun kualitas, maupun penggabungan akan keduanya. Penelitian sebelumnya banyak mengkaji secara terpisah perencanaan SDM dari sisi kuantitas melalui analisis beban kerja seperti yang disampaikan Diana dan Harta (2017) tentang pentingnya analisis beban kerja terhadap penataan beban kerja suatu organisasi. Maupun dari sisi kualitas dapat dikaji melalui analisis gap kompetensi seperti merujuk pada Azmi (2015) dan Fadhil (2016) tentang pentingnya manfaat untuk mengembangkan kompetensi SDM terutama dilakukan dalam mencapai tujuan organisasi secara berkelanjutan. Pada penelitian ini proses mendapatkan tendik yang dibutuhkan melalui perencanaan SDM terhadap tendik yang sudah ada maupun yang baru akan direkrut maka berusaha menggabungkan dua analisis tersebut, yaitu analisis beban kerja untuk sisi kuantitas dan analisis gap kompetensi untuk sisi kualitas tendik yang dibutuhkanpada Fakultas A Universitas XYZ.

Pentingnya perencanan SDM pada institusi pendidikan tinggi, disadari sepenuhnya oleh Universitas XYZ dalam menjalankan proses bisnisnya, harus didukung oleh SDM baik dosen maupun tendik yang berkualitas dan kompeten. Selain dosen dan mahasiswa yang terlibat dalam serangkaian proses bisnis tersebut, ada peran tendik tidak boleh dipandang sebelah mata bahkan diabaikan. Tendik memiliki kontribusi yang tidak sedikit untuk membuat semua proses bisnis pendidikan tinggi di Univesitas XYZ berjalan baik. Berikut adalah profil ketenagaan dosen dan pegawai pada Universitas XYZ sampai dengan Desember 2018, seperti terlihat pada Tabel 1.

Tabel 1. Jumlah SDM Tenaga Pendidik dan Tenaga Kependidikan di Universias XYZ (Desember 2018)

\begin{tabular}{lcc}
\hline \multirow{2}{*}{ Kategori SDM } & \multicolumn{2}{c}{ Status } \\
\cline { 2 - 3 } & PNS (orang) & Non PNS (orang) \\
\hline Tenaga Pendidik & 1.256 & 151 \\
(Dosen) & & 1.357 \\
$\begin{array}{l}\text { Tenaga Kependidikan } \\
\text { (Tendik) }\end{array}$ & 1.348 & \\
\hline Jumlah & \multicolumn{2}{c}{4.112} \\
\hline
\end{tabular}

Melihat data ketenagaan pada Universitas XYZ tersebut, hal itu menunjukan bahwa Universitas XYZ adalah satu institusi yang besar, yang memiliki jumlah pegawai kurang lebih 4.112 orang. Tentu bukan hal yang mudah mengelola SDM yang besar tersebut. Salah satu kunci penyelesaian permasalahan SDM yang banyak tersebut adalah dengan perencanaan SDM yang baik.

Fakultas A sebagai salah satu fakultas di Universitas XYZ yang tumbuh dan berkembang pesat, dengan jumlah mahasiswa aktif tidak kurang dari 2.000 orang setiap tahunnya. Mendukung semua pergerakan dan tuntutan tersebut, maka perlu SDM yang memadai dan berkualitas, salah satunya adalah tendik yang sesuai baik dari sisi jumlah maupun kompetensinya. Berdasarkan data dari Kepegawaian Fakultas A diperoleh data ada 97 tendik yang terdiri dari 40 orang berstatus PNS dan 57 orang yang berstatus sebagai pegawai non PNS yang tersebar pada lima departemen dan dekanat Fakultas A Universitas XYZ tersebut. Sementara data dari Manpower Planning yang dirilis Direktorat SDM Universitas XYZ menyebutkan bahwa jumlah ideal 
tendik untuk Fakultas A adalah berjumlah 53 orang. Tentu hal tersebut menjadi permasalahan tersendiri yang perlu dikaji lebih mendalam melalui penelitian perencanaan SDM tendik pada Fakultas A saat ini.

Analisis beban kerja menurut Pranoto dan Retnowati (2015) merupakan metode untuk menghitung beban kerja sehingga bisa dihitung jumlah tenaga kerja yang dibutuhkan untuk menyelesaikan beban kerja tersebut. Satuan yang dipakai menghitung kebutuhan tenaga kerja atau orang untuk menyelesaikan suatu pekerjaan sering disebut dengan Full Time Equivalent (FTE). Sedangkan kompetensi berdasarkan UU RI No. 13 (2003) tentang Ketenagakerjaan, merupakan kemampuan kerja setiap individu yang mencakup aspek pengetahuan, keterampilan, dan sikap kerja yang sesuai dengan standar yang ditetapkan. Sedangkan komptensi berdasarkan UU RI No. 13 (2003) tentang Ketenagakerjaan, merupakan kemampuan kerja setiap individu yang mencakup aspek pengetahuan, keterampilan, dan sikap kerjayang sesuai dengan standar yang ditetapkan. Adapun variabel yang digunakan dalam analisis beban kerja adalah rincian aktivitas inti dan tambahan tendik pada berbagai jabatan tendik yang telah dirilis oleh Direktorat SDM terhadap lebih dari 50 jenis jabatan tendik yang ada di Universitas XYZ. Sedangkan untuk kompetensi, variabel yang diteliti pada penelitian ini adalah kompetensi inti dan kompetensi manajerial. Kompetensi inti terdiri dari 6 indikator dan kompetensi manajerial yang terdiri dari 7 indikator seperti yang tercantum dalam Pedoman Pengelolaan SDM pada Universitas XYZ.

Hasil analisis beban kerja dan gap kompetensi tersebut diharapkan dapat dibuat suatu perencanaan SDM yang tepat dan terstruktur baik dari sisi jumlah maupun dari sisi kompetensi. Keberadaan tendik yang tepat dan sesuai baik secara kuantitas maupun kualitas tentu sangat berpengaruh terhadap pencapaian visi, misi dan tujuan Fakultas A agar dapat berjalan lebih baik, efektif dan efisien, sejalan dengan pernyataan Fapohunda (2015) bahwa perencanaan kuantitas dan kualitas tendik pada perguruan tinggi adalah hal yang sangat penting.

Tujuan penelitian ini adalah untuk untuk menganalisis beban kerja dan gap kompetensi tendik pada Fakultas A Universitas XYZ, dan merekomendasikan perencanaan SDM tendik di Fakultas A Universitas XZY saat ini dan kedepannya. Sedangkan ruang lingkup penelitian ini dibatasi pada perencanaan SDM terhadap tendik di Fakultas A, Universitas XYZ terkait dengan sisi kuantitas maupun kualitas dalam hal ini adalah kompetensi yang dimiliki tendik saat ini, bila dibandingkan dengan kesesuaian kuantitas dan kualitas yang seharusnya dibutuhkan oleh tendik Fakultas A itu sendiri.

\section{METODE PENELITIAN}

Penelitian ini dimulai Maret sampai dengan Juli 2019. Adapun lokasi penelitian adalah bertempat di Fakultas A Universitas XYZ, beserta unit kerja yang ada dibawahnya. Penelitian ini menggunakan dua data sekaligus, yaitu data primer dan data sekunder. Data primer untuk analisis beban kerja diperoleh melalui pengamatan langsung dan mengajukan pertanyaan sesuai dengan rangkaian aktivitas tendik pada jabatan tendik masing-masing seperti yang telah dirilis oleh Direktorat SDM terhadap 50 lebih jabatan tendik. Sedangkan untuk data primer analisis gap kompetensi diperoleh dari kuisioner yang diisi oleh seluruh tendik beserta atasan langsung tendik yang bersangkutan. Sedangkan data sekunder diperoleh dari data-data tendik baik yang berada di tingkat departemen, fakultas maupun pada Direktorat SDM Universitas XYZ, juga dilakukan penelusuran penelitian terdahulu baik buku, jurnal dan lainnya. Responden pada penelitian ini adalah seluruh tendik yang dimiliki oleh Fakultas A yang berstatus Pegawai Negeri Sipil atau PNS maupun non PNS. Saat ini, Fakultas A memiliki tendik berjumlah 97 orang, dimana 40 orang berstatus PNS dan sisanya 57 orang berstatus non PNS.

Pengambilan data primer untuk analisis beban kerja dimulai dengan mengklasifikasi berdasarkan nama jabatan pekerjaan, baik yang ada di level fakultas, departemen, maupun program studi. Salah satu tahapan terpenting selanjutnya adalah menentukan waktu efektif kerja untuk tahun 2019 dengan memperhatikan beberapa faktor diantaranya hari libur nasional, asumsi cuti tahunan, libur akhir pekan dan lainnya sehingga diperoleh waktu efektif bekerja baik dalam bentuk jam pertahun, menit pertahun maupun detik pertahun. Tahapan berikutnya dilanjutkan dengan menentukan beban kerja masing-masing tendik pada setiap jenis pekerjaan yang ada dengan menggunakan metode FTE. Hasil dari analisis beban kerja ini diharapkan akan diperoleh data yang tepat terkait dengan jumlah tendik yang berada di Fakultas A tersebut yang masuk pada kategori underload, fix atau Overload. 
Pengambilan data pada analisis gap kompetensi diawali dengan pembuatan kamus kompetensi dengan menggunakan variabel kompetensi yang terdiri dari kompetensi inti dan kompetensi manajerial dengan melibatkan pakar untuk menskoring setiap indikator untuk semua jabatan pekerjaan tendik yang ada di Fakultas A yang sebanyak 17 jabatan pekerjaan tendik. Adapun pakar yang menskoring tersebut terdiri dari dua orang Kasubdit Direktorat SDM Universitas XYZ dan 5 orang Sekretaris Departemen yang berapa dibawah Fakultas A, Universitas XYZ. Berdasarkan kamus kompetensi jabatan yang telah dibuat tersebut kemudian diperbandingkan dengan kompetensi masing-masing tendik baik berdasarkan penilaian atasan maupun penilaian diri sendiri yang diperoleh dari kuesioner dan wawancara yang dilakukan pada responden maupun atasan langsung responden tersebut.

Jabatan para Kepala Tata Usaha dinilai oleh para Sekretaris Departemen dan Wakil Dekan bidang SKP. Sedangkan untuk tendik dibawah Kepala Tata Usaha dilakukan penilaiannya oleh Kepala Tata Usaha disetiap unit kerja tersebut. Para atasan langsung tersebut melakukan penilaian kesenjangan atau gap terhadap berdasarkan kamus kompetensi untuk setiap jabatan pekerjaan tendik. Selain itu sebagai pembanding maka dibuat juga penilaian diri sendiri oleh masing-masing tendik, sehingga semua tendik tersebut akan mempunyai 2 tabel gap kompetensi, yaitu gap kompetensi berdasarkan penilaian atasan dan gap kompetensi berdasarkan penilaian diri sendiri. Perhitungan gap kompetensi tersebut merujuk pada Aprianto dan Jacob (2013).

Menurut Muchransyah dan Rahmawati (2016), analisis beban kerja perlu dilakukan dalam perencanaan SDM untuk mendapatkan pola perencanaan SDM yang terarah dan berkesinambungan. Analisis gap kompetensi juga sangat penting dalam perencanaan SDM seperti yang disampaikan Pattiasina et al. (2016) kompetensi sebagai karakteristik dasar dari seseorang yang memungkinkan mereka mengeluarkan kinerja superior dalam pekerjaannya, dengan mengevaluasi kompetensi yang dimiliki seseorang, kita akan dapat memprediksikan kinerja orang tersebut. Pada penelitian ini, rangkaian daftar tugas dan fungsi (tusi) utama maupun tambahan yang dipakai pada analisis beban kerja maupun kuesioner analisis gap kompetensi tersebut berisikan variabel yang telah ditetapkan oleh Direktorat SDM Universitas XYZ pada Kompilasi
Manpower Planning Fakultas dan Departemen tahun 2012-2030 serta Pedoman Pengelolaan SDM pada Universitas XYZ.

Teknik pengamatan dan wawancara responden untuk analisis beban kerja menggunakan rangkaian tusi masing-masing pekerjaan tendik yang telah ditetapkan sebelumnya dalam analisis jabatan oleh Direktorat SDM Universitas XYZ terhadap hampir 50 jenis jabatan tendik dan untuk pengolahan analisis beban kerja menggunakan perhitungan FTE yang berbasiskan waktu dengan cara mengukur lama waktu penyelesaian pekerjaan yang kemudian waktu tersebut dikonversi kedalam indeks nilai FTE (Anisa dan Prastawa, 2019), dan hal tersebut dilakukan terhadap 17 jenis jabatan pekerjaan tendik pada 97 orang tendik di Fakultas A. Setelah nilai FTE semua responden dihitung, maka akan dapat diketahui masing-masing tendik masuk pada kategori underload, fix atau Overload. Adapun kategori tersebut berdasarkan Adawiyah dan Sukmawati (2013) dimana hasil FTE dikelompokkan kedalam tiga kategori, yakni underload (FTE $<1,00)$, fit ( $\mathrm{FTE}=1,00$ 1,30), dan Overload (FTE $>1,30)$.

Pada analisis gap kompetensi menggunakan variabel kompetensi yang sebelumnya telah ditetapkan oleh Universitas XYZ dalam Pedoman Pengelolaan SDM Universitas XYZ yang terdiri dari kompetensi inti dan kompetensi manajerial. Terkait dengan analisis gap kompetensi, mengharuskan ada kamus kompetensi yang akan dijadikan bahan pembanding terhadap kompetensi tendik, baik kompetensi berdasarkan penilaian atasan maupun penilaian oleh diri sendiri, seperti Kristanto et al. (2017) sampaikan bahwa perilaku setiap pegawai dapat dicocokkan dengan perilaku rujukan dari kamus kompetensi. Lebih lanjut, Isnainia et al. (2016) menyampaikan bahwa penyusunan sebuah kamus kompetensi sangat penting untuk pemangku jabatan dan mengidentifikasi kompetensi untuk pemangku jabatan tersebut.

Berdasarkan penjelasan sebelumnya maka hipotesa awal dari penelitian ini adalah keberadaan tendik eksisting pada Fakultas A saat ini belum sepenuhnya sesuai dengan yang dibutuhkan baik dari sisi jumlah maupun kompetensi. Padahal ketepatan penentuan jumlah dan kompetensi tendik yang dibutuhkan Fakultas A sangat penting terhadap pencapaian visi, misi serta tujuan dari Fakultas A itu sendiri, seperti dijelaskan oleh Kalammollah dan Anggraini (2016). Oleh sebab 
itu, kedua alat analisis tersebut diharapkan dapat menjawab kondisi tendik di Fakultas A, Universitas XYZ. Hal ini perlu dilakukan karena selama ini dirasa terlampau banyak jumlahnya dengan kompetensi yang masih belum memadai serta dapat membuat suatu perencanaan SDM yang baik dan tepat terhadap tendik yang ada di Fakultas A saat ini. Kerangka pemikiran penelitian tercantum pada Gambar 1.

\section{HASIL}

\section{Karakteristik Tendik pada Fakultas A}

Berikut akan dipaparkan karakteristik tendik yang menjadi responden pada penelitian ini. Karakteristik terebut berdasar pada berbagai jenis kategori yang diperoleh dari penyebaran kuesioner. Sebagaimana terlihat pada Tabel 2. Karakteristik tendik berstatus PNS berdasarkan jenis kelamin, memiliki dominasi yang sama yaitu laki-laki dan perempuan sama banyaknya yaitu sebanyak 20 orang atau $50 \%$ dari populasi tendik berstatus PNS, sedangkan untuk kategori usia, tendik PNS banyak didominasi oleh usia 35-39 tahun, dengan tingkat pendidikan paling mendominasi adalah setingkat SMA dan Strata S1. Adapun dominasi tendik PNS berdasarkan masa kerja didominasi oleh tendik dengan masa kerja 1-10 tahun dengan tenggang masa menuju pensiun antara 16-20 tahun kedepan. Sedangkan karakteristik tendik non PNS banyak didominasi oleh tendik laki-laki dengan mayoritas tendik berpendidikan terakhir setingkat SMA dan usia paling banyak adalah antara 35-39 tahun. Sebagian besar tendik non PNS yang ada di Fakultas A telah bekerja antara 1-10 tahun, dan lebih dari $80 \%$ dari tendik non PNS tersebut berstatus tenaga kontrak. Berikut pada Tabel 3 disajikan juga komposisi tendik berdasarkan kelas jabatannya, hal tersebut disajikan bertujuan untuk dapat diketahui kelas jabatan yang memiliki tendik dengan kategori underload terbanyak, yang tentu sangat berguna dalam menentukan perencanaan SDM tendik kedepannya.

Berdasarkan data yang tersaji pada Tabel 3 dapat dilihat bahwa untuk tendik PNS didominasi oleh tendik dengan kelas jabatan 5 sebagai pengadministrasi pada segala bidang pekerjaan sebanyak 30 orang atau sebesar 75\% dari total tendik PNS yang ada di Fakultas A, sisanya ada pada kelas jabatan 11, 10 dan 6, begitu juga untuk tendik berstatus non PNS sama didominasi oleh kelas jabatan 5 sebagai pengadministrasi dengan jumlah 31 orang atau sebesar 53,39\% dari seluruh tendik non PNS yang ada, sisanya berada pada kelas jabatan 6,4 , dan 3.

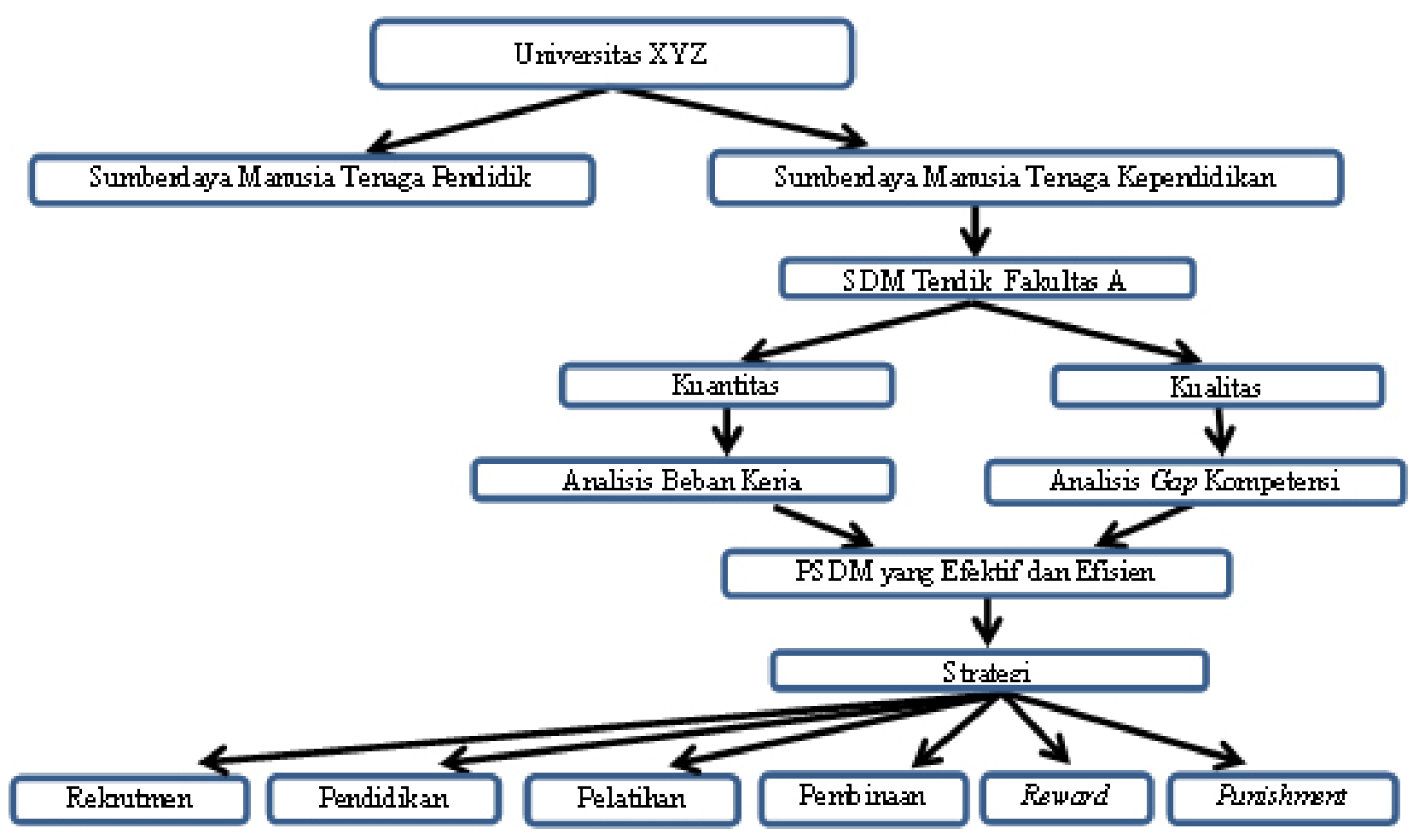

Gambar 1. Kerangka pemikiran penelitian 


\section{Analisis Beban Kerja dan Gap Kompetensi Tendik Pada Fakultas A Universitas XYZ}

Setelah analisis beban kerja dilakukan pada semua reponden. Baik yang berstatus PNS maupun non PNS yang total seluruhnya berjumlah 97 orang. Maka dapat dilihat hasilnya seperti pada Tabel 4. Tabel 4 memperlihatkan hasil analisis beban kerja pada seluruh tendik di Fakultas A diperoleh data bahwa tendik yang masuk dalam kategori underload adalah sebanyak $32,10 \%$, kategori fix sebanyak $64,16 \%$ dan pada kategori Overload sebesar 3,74\%. Hal tersebut dapat diartikan bahwa tendik yang memiliki beban kerja yang sesuai dengan bagian pekerjaannya masingmasing di Fakultas A adalah sebesar lebih dari 64\%, namun disamping itu masih ada juga tendik yang masuk kedalam kategori underload dengan presentasi yang relatif cukup besar juga sekitar $32 \%$, selain itu terdapat tendik yang masuk pada kategori Overload, walau jumlahnya relatif kecil yaitu sekitar 3\% saja. Selain sebaran tendik berdasarkan kategori nilai FTE, maka berikut ini akan disampaikan juga data mengenai sebaran tendik perkelas jabatan berdasarkan kategori nilai FTE, seperti yang terlihat pada Gambar 2.

Tabel 2. Karakteristik Tendik PNS dan Non PNS di Fakultas A Universitas XYZ

\begin{tabular}{lcccc}
\hline & \multicolumn{3}{c}{ Mayoritas } \\
\cline { 2 - 5 } Kategori & \multicolumn{2}{c}{ PNS } & \multicolumn{2}{c}{ Non PNS } \\
\cline { 2 - 5 } & Jumlah (Orang) & Persentase & Jumlah (Orang) & Persentase \\
\hline Jenis Kelamin Laki-laki & 20 & $50 \%$ & 33 & $57,89 \%$ \\
Jenis Kelamin Perempuan & 20 & $50 \%$ & 24 & $42,11 \%$ \\
Tingkat Pendidikan SMA & 14 & $35 \%$ & 29 & $50,88 \%$ \\
Tingkat Pendidikan Strata 1 & 13 & $32,5 \%$ & 20 & $35,09 \%$ \\
Usia 35-39 tahun & 14 & $35 \%$ & 33 & $57,9 \%$ \\
Masa Kerja 1-10 tahun & 23 & $57,5 \%$ & - & - \\
Waktu Pensiun 16-20 tahun kedepan & 19 & 47,5 & - & $94,21 \%$ \\
Status Kontrak Tenaga Kontrak Tenaga & - & & 9 & $15,79 \%$ \\
Tidak Dikontrak & & & & \\
\hline
\end{tabular}

Tabel 3. Komposisi tendik berdasarkan kelas jabatan

\begin{tabular}{cccccc}
\hline \multirow{2}{*}{ Kelas Jabatan } & \multicolumn{2}{c}{ PNS } & \multicolumn{2}{c}{ Non PNS } \\
\cline { 2 - 5 } & Jumlah (Orang) & Persentase & Jumlah (Orang) & Persentase \\
\hline 11 & 1 & 2,5 & - & - \\
10 & 5 & 12,5 & - & - \\
9 & - & - & - & - \\
8 & - & - & - & - \\
7 & - & - & - & - \\
6 & 4 & 10 & 5 & 8,77 \\
5 & 30 & 75 & 31 & 53,39 \\
4 & - & - & 10 & 17,54 \\
3 & - & - & 11 & 19,30 \\
2 & - & - & - & - \\
1 & - & - & - & - \\
\hline Jumlah & 40 & 100 & 57 & 100 \\
\hline
\end{tabular}

Tabel 4. Sebaran tenaga kependidikan pada fakultas A Universitas XYZ berdasarkan kategori nilai FTE

\begin{tabular}{lcc}
\hline Kategori & Jumlah (orang) & Persentase (\%) \\
\hline Underload & 31 & 32,10 \\
Fix & 63 & 64,16 \\
Overload & 3 & 3,74 \\
\hline Jumlah & 97 & 100 \\
\hline
\end{tabular}




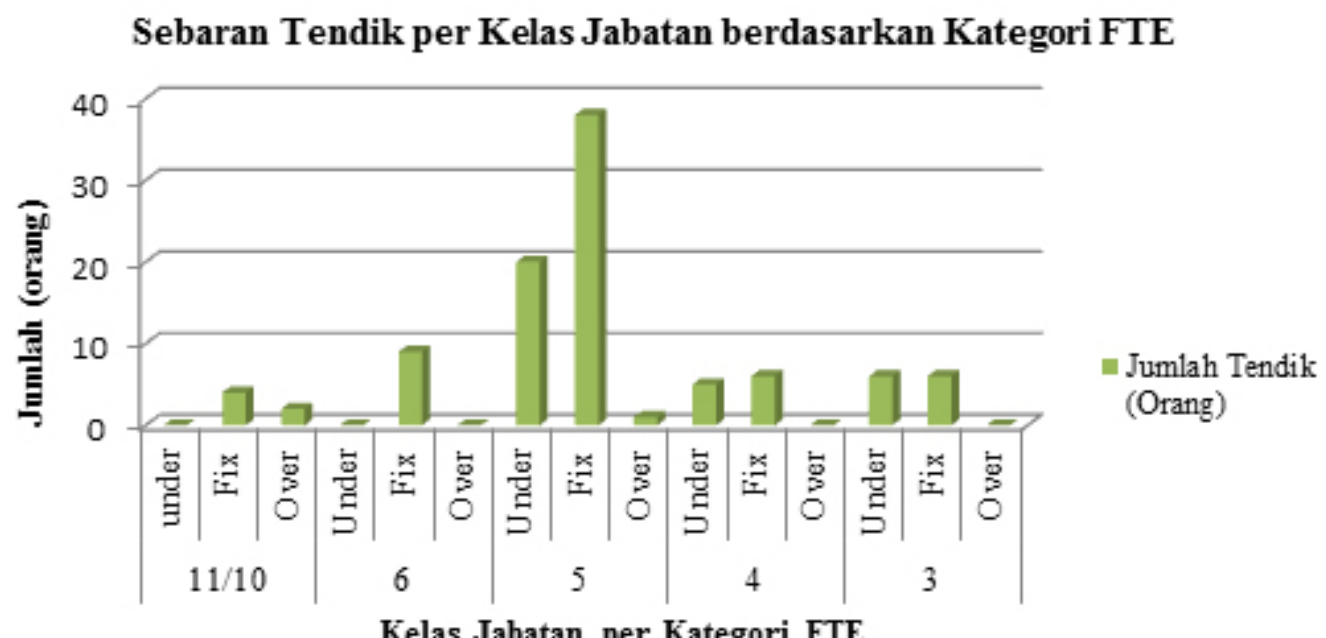

Gambar 2. Rekapitulasi jumlah tendik berdasarkan kategori FTE per kelas jabatan

Berdasarkan Gambar 2 tersebut dapat dilihat bahwa tendik didominasi oleh mereka yang memiliki kelas jabatan 5, 4 dan 3 yaitu sebagai pengadministrasian pada beberapa bidang, caraka, pramukantor dan pengemudi dengan kategori nilai FTE fix dan underload yang paling banyak, yaitu hampir lebih dari separuh tendik yang ada di Fakultas A. Lebih rincinya adalah bahwa tendik yang berada pada kelas jabatan 5 dengan kategori underload sebanyak 20 orang dan kategori fix sebanyak 38 orang dan Overload sebanyak 1 orang. Begitupun pada kelas jabatan 4 dan 3 yang relatif banyak juga tendik yang masuk pada kategori underload. Gambar diatas dapat dengan jelas menggambarkan tendik pada kelas jabatan 5, 4 dan 3 dengan kategori nilai FTE yang underload yang seharusnya dapat lebih difokuskan untuk dilakukan kebijakan pengurangan tendik berdasarkan pendekatan kebutuhan tendik dan peraturan yang berlaku juga tentunya. Berdasarkan penelusuran dilapangan keberadaan tendik yang masuk kategori underload tersebut adalah beberapa tendik yang berada pada jabatan pekerjaan yang sama, karena terlalu banyak tendik pada jabatan pekerjaan tersebut menjadikan keberadaannya kurang efektif.

Selanjutnya, selain analisis beban kerja dilakukan juga analisis gap kompetensi. Melalui analisis gap kompetensi ini akan akan diperoleh gap kompetensi untuk masing-masing responden terhadap kompetensi inti maupun kompetensi manajerial, Adapun hasil analisis gap kompetensi tersebut menunjukan bahwa sebagian besar tendik yang ada pada Fakultas A masih memiliki gap yang relatif tinggi. Gambar 3 memperlihatkan hasil analisis gap kompetensi bahwa pada kompetensi inti maupun kompetensi manajerial tendik di Fakultas A masih memiliki gap kompetensi yang relatif tinggi terutama pada kompetensi yang berkaitan dengan pekerjaan pada tatanan organisasi dalam arti yang lebih luas, sebagaian besar tendik masih bekerja sesuai pada tusinya masing-masing belum sampai tatanan yang berorientasi pada komunitas apalagi sampai dengan menghasilkan inovasi terbaru pada pekerjaan yang mereka emban. Begitupun dengan kompetensi manajerial, beberapa indikator yang dianggap masih memiliki gap yang tinggi diantaranya adalah indikator kepemimpinan, dan bekerja dalam kelompok sehingga menjadi kesatuan satu sama lain dengan pekerjaan lainnya untuk terwujudnya visi, misi dan tujuan dari Fakultas A itu sendiri. Tingginya gap kompetensi tersebut jika dibiarkan dimasa datang akan membuat ketidakberhasilan pengembangan SDM berbasis kompetensi pada organisasi tersebut, Efendi (2015), sehingga penting untuk segera dibenahi.

Hasil kedua analisis tersebut dimana masih terdapat sejumlah tendik dengan kategori underload dan dengan gap kompetensi yang tinggi, nyatanya memperlihatkan kesesuaian dengan latar belakang responden. Berdasarkan analisis deskriptif sebelumnya disebutkan bahwa Fakultas A didominasi tendik dengan pendidikan terakhir adalah SMA dengan usia yang relatif masih muda, yang belum banyak memiliki pengalaman bekerja.

\section{Perencanaan SDM Tendik di Fakultas A Universitas XZY}

Terkait dengan tujuan akhir dari penelitian ini yaitu adanya rekomendasi terhadap perencanaan SDM tendik pada Fakultas XYZ, maka berdasarkan hasil kedua analisis tersebut juga dapat dibuat rekomendasi 
perencanaan tendik yang berdasarkan pola pengefektifan fungsi pekerjaan yang seharusnya diisi oleh tendik dengan beban kerja yang fix dan dengan kompetensi yang memadai, sehingga pada akhirnya menghasilkan jumlah tendik yang sesuai dengan yang seharusnya dibutuhkan oleh Fakultas A bila dibandingkan dengan tendik versi manpower planning maupun versi kondisi eksisting saat ini seperti yang terlihat pada Tabel 5.

Seperti yang terlihat pada Tabel 5 tersebut, bahwa total selisih tendik ideal yang seharusnya dimiliki oleh
Fakultas A menurut manpower planning yang dirilis Direktorat SDM Universitas XYZ dengan jumlah tendik hasil analisis beban kerja adalah kurang sebanyak 28 orang tendik. Artinya, dengan adanya kemajuan dan perkembangan yang ada pada Fakultas A, termasuk didalamnya dengan adanya departemen baru maka jumlah tendik ideal yang mesti dimiliki oleh Fakultas A versi buku manpower planning tersebut sudah tidak relevan lagi dipergunakan sebagai bahan acuan perencanaan SDM tendik pada Fakultas A, harus ada penambahan sekitar 28 orang dengan berbagai jabatan untuk sampai pada jumlah tendik yang ideal.

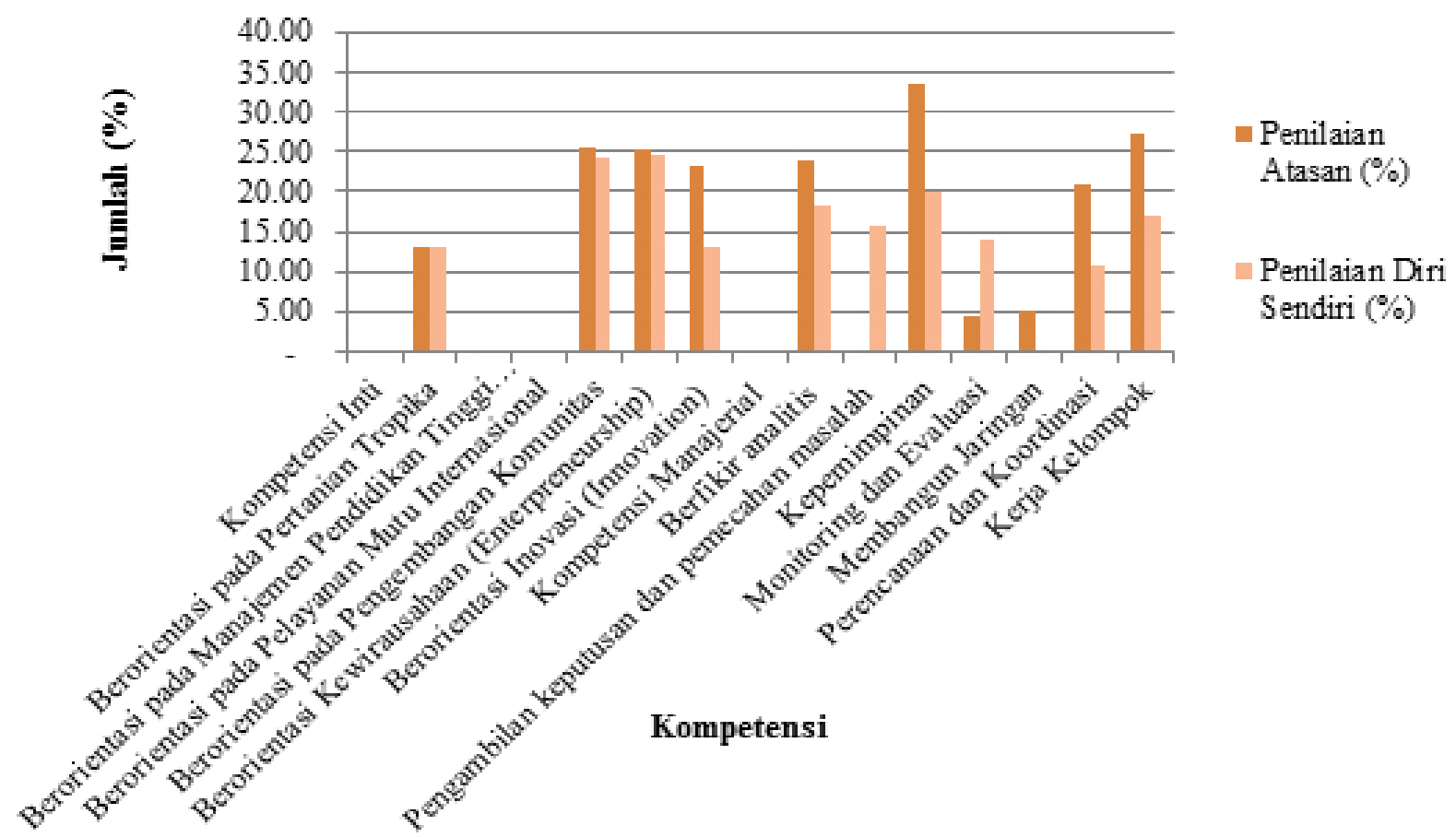

Gambar 3. Rekapitulasi Gap kompetensi tendik pada FEM berdasarkan penilaian atasan dan diri sendiri

Tabel 5. Rekapitulasi perbandingan jumlah tenaga kependidikan menurut manpower planning SDM Universitas XYZ dan kondisi eksisting fakultas A dibandingkan dengan hasil analisis beban kerja

\begin{tabular}{lcccccc}
\hline Unit Kerja & $\begin{array}{c}\text { Versi } \\
\text { Manpower } \\
\text { Planning }\end{array}$ & $\begin{array}{c}\text { Versi Hasil } \\
\text { Analisis Beban } \\
\text { Kerja }\end{array}$ & $\begin{array}{c}\text { Selisih } \\
\text { Versi Kondisi } \\
\text { Eksisting }\end{array}$ & $\begin{array}{c}\text { Versi Hasil } \\
\text { Analisis Beban } \\
\text { Kerja }\end{array}$ & Selisih \\
\hline Dekanat Fakultas A & 11 & 16 & -5 & 20 & 16 & 4 \\
Departemen Satu & 10 & 12 & -2 & 13 & 12 & 1 \\
Departemen Dua & 11 & 16 & -5 & 18 & 16 & 2 \\
Departemen Tiga & 11 & 14 & -3 & 19 & 14 & 5 \\
Departemen Empat & 10 & 13 & -3 & 16 & 13 & 3 \\
Departemen Lima & 0 & 10 & -10 & 11 & 10 & 1 \\
\hline Total & 53 & 81 & -28 & 97 & \multicolumn{3}{c}{ Lebih 16 orang } \\
\hline Selisih & \multicolumn{7}{c}{ Kurang 28 orang } \\
\hline
\end{tabular}


Selisih antara kondisi eksisting saat ini dengan jumlah tendik yang seharusnya dimiliki oleh Fakultas A berdasarkan analisis beban kerja berjumlah kelebihan 16 orang. Artinya, pada kondisi eksisting saat ini terdapat kelebihan tendik sebanyak 16 orang. Sehingga perlu adanya kebijakan pengurangan tendik terutama pada jenis pekerjaan tertentu, sesuai dengan kebijakan pengurangan tendik yang sedang dirintis oleh Direktorat SDM Universitas XYZ, dimana terdapat rasio untuk beberapa jenis jabatan pekerjaan yang hanya diperbolehkan sebanyak 1 orang setiap unit. Begitupun dengan bagian administrasi akademik harus sesuai dengan rasio yang ditentukan dimana 1 orang tendik administrasi akademik banding 200 orang mahasiswa untuk tingkat departemen dan 1 tendik akademik banding 1.000 orang mahasiswa yang dilayaninya untuk ditingkat fakultas.

Hasil penelitian ini pun mendapati bahwa setiap unit kerja dalam hal ini adalah departemen yang ada dibawah Fakultas A memiliki karakteristik yang berbedabeda, tidak dapat menyamaratakan tingkat kebutuhan dan berapa banyak tendik yang harusnya dimiliki. Baik dekanat maupun departemen yang ada dibawah Fakultas A dengan karakteristiknya masing-masing. Oleh sebab itu, diperlukan kerja sama dan koordinasi yang baik dan holistik antara Direktorat SDM, fakultas maupun departemen dalam menyusun beban kerja organisasi dan menurunkannya pada kebutuhan tendik setiap unit sehingga data kebutuhan tendik menjadi lebih valid dan tepat.

Pada satu sisi yang lain berdasarkan perhitungan FTE terhadap semua populasi tendik yang ada di Fakultas A saat ini, diperoleh data bahwa banyaknya tendik yang menempati jabatan tertentu perlu ditata sedemikan rupa sesuai dengan rasio sehingga tidak terdapat kelebihan tendik. Perlu ditata kembali tusi setiap tendik. Kebijakan pengurangan tendik terutama membidik tendik non PNS dengan beban kerja yang rendah dan gap kompetensi yang tinggi, akan membuat proses bisnis pada Fakultas A menjadi lebih efektif jika hal tersebut dilakukan, sebagaimana dijelaskan Allui dan Sahni (2016) tentang pengefektifan SDM pada lembaga pendidikan tinggi. Dasar dari pengurangan tendik tersebut dapat ditujukan terutama membidik pada tendik yang berstatus non PNS dengan beban kerja yang underload dan gap kompetensi yang tinggi. Hal tersebut sejalan dengan yang sedang dilakukan oleh Direktorat SDM Universitas XYZ dimana mulai dilakukan penjenjangan status tendik non
PNS baik itu tendik tetap, tendik kontrak, tendik non kontrak yang disebut juga tenaga harian lepas (THL). Muara akhir dari penggunaan kedua alat analisis yang telah digunakan sebelumnya, adalah dapat dibuat perencanaan SDM tendik untuk waktu mendatang yang didalamnya berisikan tentang ketersediaan tendik saat ini, tendik yang pensiun serta kebutuhan tendik ideal tahun mendatang seperti pada Tabel 6 .

Tabel 7 diatas memperlihatkan bezetting tendik yang ada pada Fakultas A untuk tahun 2019 dan 2020. Data tersebut diperoleh setelah menggunakan alat analisis beban kerja untuk penentuan jumlah tendik yang semestinya dimiliki oleh Fakultas A. Kemudian dilanjutkan dengan penggunaan alat analisis gap kompetensi yang digunakan untuk menentukan tendik yang seharusnya dapat dikurangi jumlahnya dengan salah satu pertimbangnnya adalah status kepegawaian terutama yang masih berstatus non PNS dengan beban kerja yang rendah dan gap kompetensi yang relatif tinggi. Berdasarkan kedua alat analisis yang digunakan tersebut diperoleh jumlah tendik yang seharusnya di miliki adalah sebanyak 81 orang, dari jumlah 97 orang yang ada saat ini.

Ada beberapa alternatif perencanaan SDM terkait dengan hasil analisis beban kerja dan analisis gap kompetensi pada masing-masing tendik yang ada di Fakultas A, untuk tendik berstatus PNS hendaknya lebih dipertegas tusi masing-masing tendik dengan pola monitoring dan valuasi pekerjaan yang tepat, kebijakan memberi pelatihan, pembinaan dan pendidikan yang sesuai dengan yang dibutuhkan pada pekerjaannya masing-masing adalah hal utama yang dapat dilakukan, sebagaimana dijelaskan Menon (2015), didukung dengan penegakan punishment yang baik dan sistem reward yang berkeadilan dirasa perlu untuk lebih digalakan. Sedangkan untuk yang berstatus non PNS, tendik yang ada saat ini di Fakultas A, harus ditata sedemikian rupa mengikuti pengelolaan secara holistik yang dilakukan oleh Direktorat SDM Universitas XYZ. Selanjutnya, terkait mengenai status tendik non PNS itu sendiri, termasuk diantaranya dengan tidak mengontrak kembali tendik yang kualifikasi dan kompetensinya tidak sesuai dengan yang seharusnya dimiliki. Kebijakan pengurangan tendik non PNS yang tidak sesuai beban kerja dan kompetensinya dapat dijadikan salah satu alternatif yang dapat dipilih tentu dengan mengedepankan peraturan yang berlaku terkait hal tersebut. 
Tabel 6. Bezzeting SDM tenaga kependidikan fakultas A, Universitas XYZ

\begin{tabular}{|c|c|c|c|c|c|c|c|}
\hline \multirow{2}{*}{ Jabatan } & \multirow{2}{*}{ Hasil ABK } & \multicolumn{2}{|c|}{ Eksisting } & \multirow{2}{*}{$\begin{array}{l}\text { Bezetting } \\
2019\end{array}$} & \multirow{2}{*}{ KP 2020} & \multirow{2}{*}{$\begin{array}{l}\text { PNS yang } \\
\text { Pensiun }\end{array}$} & \multirow{2}{*}{$\begin{array}{c}\text { Bezetting } \\
2020\end{array}$} \\
\hline & & PNS & Non PNS & & & & \\
\hline Kepala Tata Usaha & 6 & 6 & 0 & 6 & 0 & 0 & 6 \\
\hline Administrasi Akademik & 15 & 9 & 6 & 15 & 0 & 0 & 15 \\
\hline Administrasi Umum/Persuratan & 6 & 4 & 5 & 6 & 0 & 1 & 5 \\
\hline Arsiparis & 1 & 1 & 0 & 1 & 3 & 0 & 1 \\
\hline Administrasi Keuangan & 0 & 4 & 3 & 0 & 0 & 0 & 0 \\
\hline Administrasi Kepegawaian & 6 & 5 & 2 & 6 & 0 & 0 & 6 \\
\hline Teknisi Komputer & 4 & 1 & 1 & 4 & 2 & 0 & 4 \\
\hline Teknisi Listrik & 0 & 0 & 0 & 0 & 0 & 0 & 0 \\
\hline Teknisi Lapangan & 0 & 0 & 0 & 0 & 0 & 0 & 0 \\
\hline Pengolah Data Akademik & 6 & 0 & 5 & 6 & 0 & 0 & 6 \\
\hline Administrasi Sarana Prasarana & 9 & 5 & 7 & 9 & 0 & 0 & 9 \\
\hline Pengelola Keuangan Unit & 6 & 4 & 2 & 6 & 0 & 1 & 5 \\
\hline Caraka & 6 & 0 & 10 & 6 & 0 & 0 & 6 \\
\hline Administrasi Perpustakaan & 1 & 0 & 1 & 1 & 1 & 0 & 1 \\
\hline Pramu Kantor & 6 & 0 & 9 & 6 & 0 & 0 & 6 \\
\hline Supir & 4 & 0 & 2 & 4 & 0 & 0 & 4 \\
\hline $\begin{array}{l}\text { Administrasi Kerjasama dan } \\
\text { Kemitraan }\end{array}$ & 1 & 0 & 1 & 1 & 0 & 0 & 1 \\
\hline Adminitrasi Jurnal & 2 & 0 & 2 & 2 & 4 & 0 & 2 \\
\hline $\begin{array}{l}\text { Administrator Pengelola Sistem } \\
\text { Informasi }\end{array}$ & 2 & 1 & 1 & 2 & 0 & 0 & 2 \\
\hline Jumlah & 81 & 40 & 57 & 81 & 10 & 2 & 89 \\
\hline
\end{tabular}

Kendati jumlah tendik untuk beberapa jabatan pekerjaan tendik yang ada di Fakulas A berlebih, namun untuk beberapa jenis jabatan tendik masih ada yang belum terpenuhi pada masing-masing unit, maka kebijakan perekrutan tendik tetap harus dilaksanakan, terutama untuk jenis pekerjaan seperti arsiparis level madya, teknisi komputer maupun administrasi jurnal, hal tersebut sejalan dengan manpower planning SDM tendik tahun 2018 yang tengah dirancang oleh Direktorat SDM Universitas XYZ.

\section{Implikasi Manajerial}

\section{Direktorat SDM Universitas XYZ}

Direktorat SDM hendaknya melakukan kerjasama yang berkesinambungan dengan Fakultas dan Departemen untuk secara periodik menentukan beban kerja organisasi dan dapat menurunkannya pada bentuk kebutuhan tendik setiap unit dibawah Fakultas A. Selain itu, perlu juga melakukan revisi indikator-indikator kompetensi inti dan manajerial yang tepat untuk tendik dan dilanjutkan dengan pembuatan kamus kompetensi untuk seluruh jabatan tendik.
Terhadap tendik PNS perlu mengutamakan kembali kebijakan dengan memperbanyak pelatihan, pembinaan serta pendidikan yang sesuai bidang pekerjaannya masing-masing, perbaikan reward dan penegakan punishment serta adanya rekuitmen terhadap beberapa jabatan tendik yang dibutuhkan, tetapi belum tersedia disetiap unit di bawah Fakultas A. Pada tendik non PNS, penerapan kebijakan status kontrak dan tidak kontrak perlu terus dikembangkan untuk lebih mengurangi jumlah tendik non PNS yang terlanjur banyak. Jika keberadaan tendik PNS non PNS terutama dengan beban kerja yang tidak fix dan gap kompetensi yang tinggi tersebut sudah tidak sesuai dan tidak diperlukan lagi dalam proses bisnis pada Fakultas A, maka pilihan kebijakan pengurangan tendik tentu dapat dipertimbangkan, sesuai dengan masukan dari fakultas dan departemen serta dengan tetap mengedepankan peraturan yang berlaku.

\section{Fakultas A, Universitas XYZ}

Secara bersama-sama untuk dapat menentukan beban kerja setiap unit dan menentukan jumlah tendik yang dibutuhkannya, walau secara holistik penentu kebijakan mengenai SDM berada pada Direktorat SDM, namun 
peran fakultas dan departemen tidak dapat diabaikan, justeru pada departemen atau unit kerja itulah ujung tombak perhitungan beban kerja dan kebutuhan tendik dapat dilakukan berdasar pada karakteristik masingmasing unit kerja tersebut. Terhadap pembuatan tusi dan kamus kompetensi inti maupun manajerial untuk seluruh tendik di Universitas XYZ, Fakultas A berserta masing-masing departemen didalamnya diharapkan dapat memberi masukan terhadap hal tersebut.

Selain itu, atasan langsung tendik pada tingkat departemen maupun fakultas untuk terus secara periodik melakukan monitoring dan evaluasi terkait dengan pelaksanaan tusi dan kompetensi masingmasing tendik, yang pada gilirannya dapat dijadikan dasar perencanaan SDM tendik kedepannya. Kebijakan resource sharing sesama unit kerja dibawah Fakultas A disarankan untuk dapat dilakukan, dimana unit kerja yang kelebihan jumlah tendik dapat mensharing tendik pada unit kerja yang membutuhkan, selama sesuai dengan kualifikasi dan kompetensi yang seharusnya dimiliki tendik tersebut. Dibandingkan harus merekrut tendik baru atau mengeluarkan tendik yang ada, namun demikian kebijakan pengurangan tendik PNS dan non PNS yang sudah tidak sesuai lagi keberadaannya merupakan alternatif perencanaan SDM yang tetap dapat dilakukan, dengan harus berpegang pada peraturan yang berlaku.

\section{KESIMPULAN DAN SARAN}

\section{Kesimpulan}

Berdasarkan hasil analisis beban kerja maka dapat disimpulkan bahwa jumlah tendik yang ada di Fakultas A belum sesuai dengan yang seharusnya dibutuhkan. Fakultas A memiliki tendik yang berlebih dari yang seharusnya dibutuhkan, sehingga kebijakan pengurangan tendik merupakan salah satu alternatifyang dapat dilakukan tentu dengan tetap mengedepankan peraturan terkait hal tersebut.

Kompetensi tendik yang dimiliki Fakultas A sampai saat ini belum sepenuhnya sesuai dengan yang semestinya dibutuhkan. Masih banyak dijumpai gap pada berbagai indikator baik pada kompetensi inti dan kompetensi manajerial. Beberapa indikator pada kompetensi inti yang dirasa masih memiliki kesenjangan yang tinggi pada tendik diantaranya adalah: Berorientasi pada Komunitas, Berorientasi pada Kewirausahaan dan
Berorientas pada Inovasi. Sedangkan untuk kompetensi manajerial indikator yang memiliki kesenjangan paling besar adalah: Kepemimpinan, Kerja Kelompok dan Berfikir Analisis.

Berdasarkan analisis beban kerja dan analisis kompetensi yang dilakukan pada penelitian ini didapat jumlah tendik yang ideal yang seharusnya dibutuhkan Fakultas A adalah berjumlah 81 orang, sementara tendik yang ada saat ini adalah 97 orang sehingga ada kelebihan 16 orang tendik. Kebijakan pengurangan tendik dapat dijadikan salah satu alternatif perencanaan SDM tendik di Fakultas A, terutama ditujukan pada tendik non PNS yang memiliki beban kerja yang sedikit dengan gap kompetensi yang tinggi.

\section{Saran}

Pada penelitian lanjutan hendaknya dilakukan tentang pembuatan kamus kompetensi untuk semua jabatan tendik yang ada di Universitas XYZ saat ini yang berjumlah kurang lebih 50 jenis jabatan pekerjaan. Selanjutnya perlu juga dilakukan penelitian tentang analisis jabatan pekerjaan termasuk didalamnya adalah analisis beban kerja tendik disetiap fakultas agar diperoleh jumlah kebutuhan tendik ideal untuk Universitas XYZ saat ini dan kedepannya. Terhadap perencanaan SDM tendik dengan alternatif kebijakan pengurangan tendik kedepannya, maka perlu diteliti lebih mendalam lagi kemungkinan dampak yang akan terjadi dengan adanya pengurangan tendik tersebut.

\section{DAFTAR PUSTAKA}

Adawiyah W, Sukmawati A. 2013. Analisis beban kerja sumber daya manusia dalam aktivitas produksi komoditi sayuran selada (Studi Kasus: CV Spirit Wira Utama). Jurnal Manajemen dan Organisasi IV(2): 128-142. http://dx.doi.org/10.29244/jmo. v4i2.12619.

Allui A, Sahni J. 2016. Strategic human resource management higher education institutions : Emperical evidence from saudi. 12th international strategic management conference. ISMC 2016. Atala. Turkey. Procedia-Social and Behavioral Sceinces 235(2016): 361-371.

Anisa NH, Prastawa H. 2018. Analisis beban kerja dengan metode full time equivalent (FTE) (study kasus pada PT. PLN (Persero) distribusi Jateng dan DIY). Industrial Engineering Journal Online 
$7(4): 1-8$.

Aprianto, Jacob. 2013. Pedoman Lengkap Profesional Sumberdaya Manusia Indonesia. Jakarta: Penerbit PPM.

Azmi, Ahmad. 2015. Pengembangan kompetensi sumberdaya manusia untuk mencapai career ready profesional di Universitas Tanri Abeng. Jurnal Binus Business Review 6(2): 220-232.

Benitez A, Castro L, Menendes L. 2016. Human Resources Management in Higher Education: the influence of the policies of regions on hiring and promotion practices at universities. SPRI Forum Early Career Researcher Conference (ECC): "Science, Innovation and the University: keys to social impact" Valencia, Spain : 1-20.

Diana BA, Harta R. 2017. Analisis beban kerja pegawai pada kantor UPBJJ-Universitas Terbuka Bandung. Jurnal Manajemen Pelayanan Publik 1(1): 1-17. https://doi.org/10.24198/jmpp. v1i1.13555.

Efendi N. 2015 Pengembangan sumberdaya manusia berbasis kompetensi di kantor pemerintahan kota bandar Lampung. Jurnal Mimbar 31(1): 1-10.

Fadhil M. 2016. Pengaruh kompetensi sumberdaya manusia terhadap kinerja pegawai pada balai latihan kerja industri Makassar. Jurnal Perspektif 1(1): 70-81.

Fahmi I. 2016. Pengantar Manajemen Sumberdaya Manusia: Konsep dan Kinerja. Jakarta: Mitra Wacana Media.

Fapohunda TM. 2015. Human resource planning and succession planning in nigeria's higher education. International Journal of Research in Management Business Studies 2(2): 59-65.

Hasibuan M. 2013. Manajemen Sumberdaya Manusia. Edisi Revisi. Jakarta: PT Bumi Aksara.

Isnainia AP, Baihaqi I, Rahmawati Y. 2016. Perencanaan kamus kompetensi manajer biro pengadaan manajer bidang komersial pada perusahaan PT. Barata Indonesia (Persero) berdasarkan kamus kompetensi spencer. Jurnal Teknik ITS 5(2): 862-865.

Kalammollah, Anggraeni. 2016. Analisis beban kerja untuk menentukan jumlah karyawan optimal pada koperasi pesantern (Kopontren) Binaan Pemerintah Kota Surabaya. Prosiding Seminar Nasional Ekonomi dan Bisnis dan Call For Paper Fakultas Ekonomi dan Bisnis UMSIDA. Surabaya: UMSIDA.

Kristanto DY, Fahmi I, Maulana A. 2017. Pengembangan kamus keselamatan kerja di PT XYZ Indonesia TBK. Jurnal Aplikasi Bisnis dan Manajemen 3(1): 1-11. https://doi.org/10.17358/ JABM.3.1.1.

Menon AS. 2015. HRM in Higher Education: The Need of the Hour. Journal of Research and Methode in Education (IORS-JRME) 5(6): 12-14.

Muchransyah MHQ, Rahmawati S. 2016. Analisis beban kerja dan kebutuhan pegawai di pusat perpustakaan dan penyebaran teknologi pertanian (PUSTAKA). Jurnal Manajemen dan Organisasi VII(2): 81-97.

Pattiasina M, Roring M, Rumawas W. 2016. Pengaruh kompetensi sumberdaya manusia terhadap kinerja karyawan PT Bank Tabungan Negara Tbk, Kantor Cabang Manado. Jurnal Adminsitrasi Bisnis 4(2): 1-6.

Rabee AM. 2014. Strategic management of human resources in educational organizations. European Scientific Journal 10(10): 292-300.

Teir RAS, Zhang RQ. 2016. The current practices of human resource management in higher education institutions in Palestine. Journal of Human Resources Management and Labor Studies 4(1): 65-83. https://doi.org/10.15640/jhrmls.v4n1a3. 